\title{
Challenges to Adoption of Improved Legume Varieties: A Gendered Perspective
}

\author{
Bezaiet Dessalegn ${ }^{1, *(\mathbb{D})}$, Woinishet Asnake ${ }^{2}$, Abiro Tigabie ${ }^{2}$ and Quang Bao Le ${ }^{1}$ (D) \\ 1 International Center for Agricultural Research in the Dry Areas (ICARDA), Cairo P.O. Box 11711, Egypt; \\ q.le@cgiar.org \\ 2 International Center for Agricultural Research in the Dry Areas, Addi Ababa P.O. Box 5689, Ethiopia; \\ w.asnake@cgiar.org (W.A.); a.tigabie@cgiar.org (A.T.) \\ * Correspondence: b.dessalegn@cgiar.org
}

check for

updates

Citation: Dessalegn, B.; Asnake, W.; Tigabie, A.; Le, Q.B. Challenges to Adoption of Improved Legume Varieties: A Gendered Perspective. Sustainability 2022, 14, 2150. https:// doi.org/10.3390/su14042150

Academic Editors: Othmane Merah, Purushothaman Chirakkuzhyil Abhilash, Magdi T. Abdelhamid, Hailin Zhang and Bachar Zebib

Received: 29 November 2021

Accepted: 27 January 2022

Published: 14 February 2022

Publisher's Note: MDPI stays neutral with regard to jurisdictional claims in published maps and institutional affiliations.

Copyright: (C) 2022 by the authors. Licensee MDPI, Basel, Switzerland. This article is an open access article distributed under the terms and conditions of the Creative Commons Attribution (CC BY) license (https:/ / creativecommons.org/licenses/by/ $4.0 /)$.

\begin{abstract}
Limited availability and access to seeds of improved varieties are often blamed for the low adoption of legume-based rotations. In this paper, we use a case study of chickpea and lentil production in Ethiopia and a gendered lens to identify other determinants of farmers' decisions for the adoption of improved legume varieties. Mixed methods were used to collect sex and age disaggregated data through 360 household surveys, 11 focus group discussions, and 8 key informant interviews. The analysis focused on key adoption parameters, including access to land, labor, improved seed varieties, fertilizers, pesticides, agriculture information, and credit. The main challenges identified include: differential access to timely and adequate seeds of improved varieties, quality fertilizers, and pesticides; availability of credit at an affordable interest rate; and equitable access to information. As compared to men, we found women's access to these resources to be low and women's cost production to be relatively high. Farmland remains a main constraint for the youth. Farmers responded to the challenges by recycling seeds and mono-cropping lentils, despite declining soil and crop productivity, and increased occurrence of pests and diseases. In the case of chickpea, we found that cultural norms also discouraged the adoption of the improved variety.
\end{abstract}

Keywords: adoption; gender; chickpea; lentil; improved seed varieties

\section{Introduction}

The adoption of improved technologies is an outcome of the optimization of costs and benefits. The propensity and speed of adoption, however, varies across individuals and is highly correlated with a farmers' ability to adopt, including their access and control over essential resources [1-4]. Among the dominant factors that influence adoption are the proximity to pioneer farmers, size of the farm, availability of labor, education, health, age and gender, compatibility of proposed intervention with farmers' demands, and farmers' perception of the relevance of the technologies to meet their needs [5-12]. Institutional frameworks, including extension and input service delivery systems, also facilitate large-scale adoption by creating enabling environments [13]. Many challenges are also experienced throughout the adoption process and could result in the dis-adoption of the technology if appropriate tracking and supporting mechanisms are not in place $[6,14]$.

The literature also identifies specific challenges associated with the diffusion of improved crop varieties, including poor extension systems that fail to raise farmers' awareness of recommended agronomic practices and the timely delivery of required services and inputs $[13,15-17]$. These studies, however, predominantly assume a homogenous society and fall short of making a distinction among different actors within a society and the differential access and control they have of key resources and production inputs. Though not directly related to the adoption of improved lentil and chickpea varieties, the literature does offer a wide range of explanations for gender-based constraints in technology adoption [18-23]. 
In this study, we used a gendered lens to determine what could be done to enhance large-scale and equitable adoption of improved legume varieties. We used a gender analytical framework to explore the specific roles of women (heads of households and those married and living with their husbands) and men (adult and youth) in agriculture, their differential access to and control over essential productive resources and services, and the cultural and structural factors that influence their adoption of selected legume varieties and associated agronomic practices.

Subsistence agriculture serves as the main pillar of the Ethiopian economy, providing employment and supporting rural livelihoods. The sector generates nearly $34 \%$ of the country's GDP and is dominated by mixed farming systems [24]. As in most developing countries, cereal dominates the production system, while the legume seed sector receives little policy attention [25]. Chickpea and lentil are among the leading grain legumes grown in the country, both in terms of area coverage and the volume of production $[15,26]$. According to the 2018 national Central Statistics Agency (CSA) report, chickpeas and lentils are grown by about 684,000 and 873,000 households on 243,000 and 119,000 ha and produce an average yield of 2.1 tons per ha for chickpea and 1.5 tons per ha for lentils, respectively [27].

Among all regions in Ethiopia, Oromia and Amhara have the largest area allocated to cereal and pulse production [27]. This is due to the favorable agro-ecology and the economic, nutritional, and environmental benefits it offers. In addition to chickpea and lentil, farmers also grow other legumes, including faba bean, field pea, white and red haricot bean, grass pea, soy bean, fenugreek, mung bean, and 'gibto' [28]. Many smallholder farmers rely on legumes as an affordable and important source of protein to improve their household food and nutrition security, to generate income, enhance soil fertility through crop rotation, supplement livestock feed, conserve water, retard soil erosion, and serve as a fuel for cooking [26,27,29-31]. However, despite the manifold benefits they offer, the productivity of grain legumes in Ethiopia remains low.

The Alamaya lentil and Kabuli chickpea varieties were introduced to the region in 2012 and have been promoted for large-scale adoption through the regional agricultural extension system. However, the adoption levels are still very low. In this study, we used a gendered lens to determine what could be done to enhance large-scale and equitable adoption of Alamaya lentil and Kabuli chickpea varieties among men, women, and youth in the study area. Our research question is underpinned by the extensive literature that confirmed that agricultural technology adoption is not gender-neutral but context-specific, and the rate of adoption of new agricultural technologies is lower among female farmers than male farmers [18-23]. In the next section, we present a brief overview of the study area, followed by the methods used to collect quantitative and qualitative data to generate the required data. We then present our findings and our analysis of the challenges and opportunities for increased adoption of improved lentil and chickpea varieties. The last section presents our conclusion.

\section{Study Area}

This study focuses on Moretina Jiru Woreda (District), located in the North Shewa Zone of the Amhara Region. The site was randomly selected from among similar cereal and pulse-producing areas in the region. The study site is presented in Figure 1.

According to the Moretina Jiru Office of Agriculture, Moretina Jiru is surrounded by the Jemma river and shares borders with Siyadebirnawayu in the south, Ensaro in the southwest, Merhabete in the northwest, Menz Keya in the northeast, and Bassonawerana in the east. The area has one main rainy season with an average rainfall of $950 \mathrm{~mm}$ per annum and has about 93,000 people with 48,000 males and 45,000 females, and has an area of $706.16 \mathrm{~km}^{2}$ and a population density of 139 people per $\mathrm{km}^{2}$, which is higher than the Zone average of 121. It is also home to 56 socially established cooperatives that play a crucial role in input supply, market access, saving and credit services, and capital accumulation. 


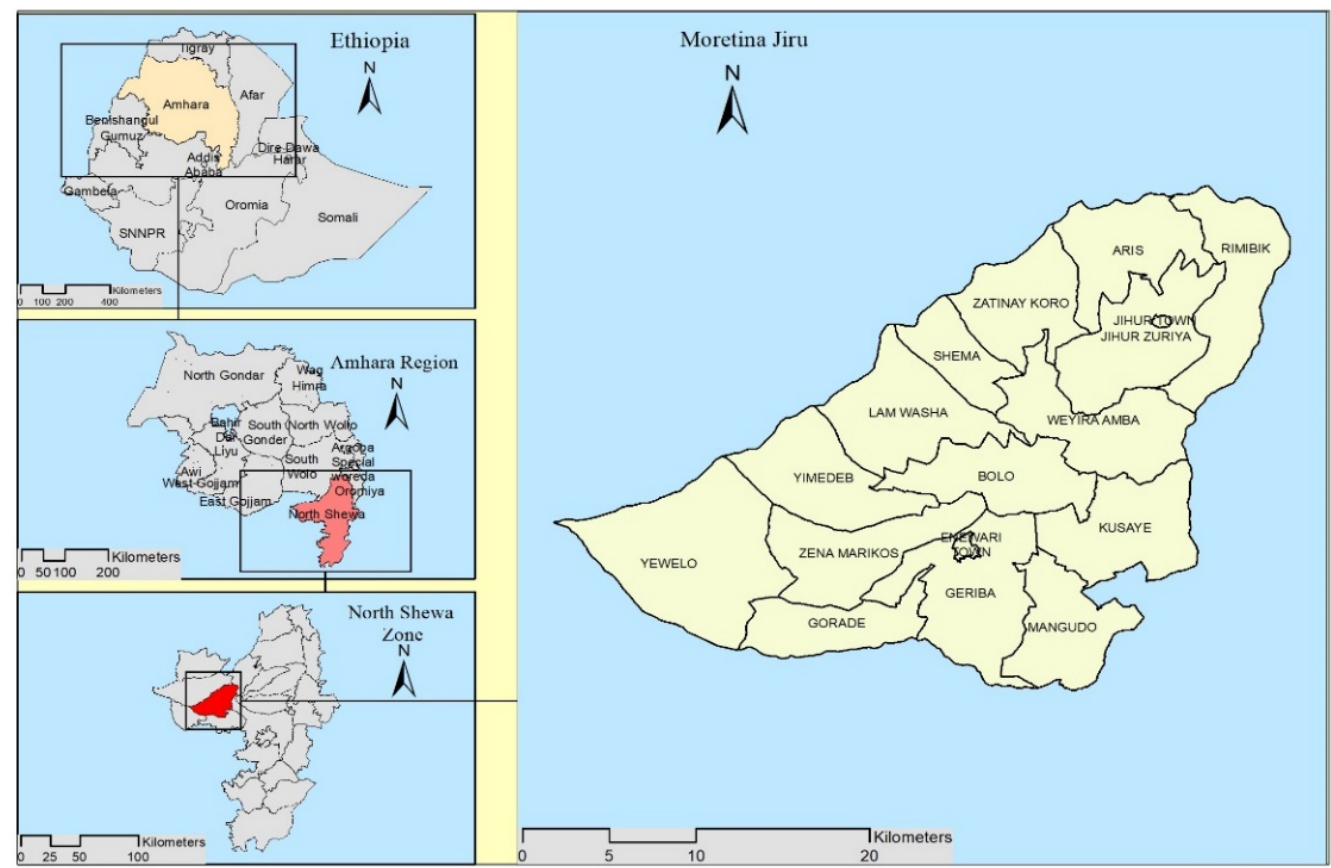

Figure 1. Study site of Moretina Jiru Woreda.

According to the Woreda Office of Agriculture, livelihoods are based on a croplivestock production system. The system is rainfed-based with occasional irrigation from small rivers, natural streams, and, on rare occasions, groundwater. Cereals and pulses are mainly grown under rainfed agriculture, while irrigation water is used to grow vegetables to generate income. Farmers also grow other crops, such as sesame, linseed, and fruits. and raise cattle, goats, equines, and poultry. The sources of animal feed in the area include communal grazing, crop residues, tree lucerne (Chamaecytisus palmensis), tree sesbania (Sesbania sesban), and industrial by-products.

\section{Methods}

Mixed methods were used to collect qualitative and quantitative data based on ethical protocols that were followed throughout the data collection process. The latter followed the Sustainable Livelihood Framework, which identifies five key forms of capital needed to respond to various shocks and remain resilient to support future generations [32]. Quantitative data on a household's social, financial, physical, human, and natural capital were collected using a survey administered to 360 farming households who grew lentil and/or chickpea in Moretna Jiru Woreda in the 2017 production season. Multi-stage purposive and random sampling techniques were used to select the households as per the following. First, potential Kebeles (villages) growing lentil and chickpea were purposively selected from the Woreda, out of which four sample kebeles-namely Jihur, Kusay, Gerba, and Mangudo-were randomly selected. Then, a list of farmers from all the villages considered was taken from each Kebele administration. An average of 90 households were then randomly selected from each of the four kebeles. The interviews were held with the household heads $(93 \%)$ or a member of the household who is considered knowledgeable about the farming activities of the household (7\%). The culturally sensitive data collection excluded the participation of women farmers, who represented only $5 \%$ of the total individuals reached through the survey. Given the potential bias that may have been introduced due to the imbalance between male and female respondents in the sample, qualitative data were collected through FGDs to verify the results of the survey data.

Qualitative data were collected from three of the four kebeles that were randomly selected and included Jihur, Kusay, and Mangudo. A total of 11 focus group discussions (FGDs) were held with 101 farmers and eight key informant interviews (KIIs) were held 
with experts engaged in the dissemination of agricultural technologies (Table 1). All the experts consulted were men, as not many women in the rural areas are educated and hold such positions. Separate FGDs were held with older male farmers (above age 45), young male farmers (18-30 years old), and female farmers involved in the production of lentil and chickpea. The small number of female farmers available for the FGDs limited our ability to classify them into young, old, household heads, and married. Semi-structured questions were used to guide the FGDs and solicit information related to the production and marketing of chickpea and lentil in the area, including the challenges and opportunities faced by the distinct groups.

Table 1. Number of farmers consulted.

\begin{tabular}{|c|c|c|c|c|c|c|c|c|c|c|c|c|c|}
\hline \multirow[t]{2}{*}{ Kebele } & \multicolumn{3}{|c|}{ Jihur } & \multicolumn{3}{|c|}{ Kusay } & \multicolumn{3}{|c|}{ Mandugo } & \multicolumn{3}{|c|}{ Gerba } & \multirow[t]{2}{*}{ Total } \\
\hline & $\begin{array}{c}\text { Male } \\
\text { (Older) }\end{array}$ & Female & $\begin{array}{l}\text { Youth } \\
\text { (Male) }\end{array}$ & $\begin{array}{l}\text { Male } \\
\text { (Older) }\end{array}$ & Female & $\begin{array}{l}\text { Youth } \\
\text { (Male) }\end{array}$ & $\begin{array}{c}\text { Male } \\
\text { (Older) }\end{array}$ & Female & $\begin{array}{l}\text { Youth } \\
\text { (Male) }\end{array}$ & $\begin{array}{c}\text { Male } \\
\text { (Older) }\end{array}$ & Female & $\begin{array}{l}\text { Youth } \\
\text { (Male) }\end{array}$ & \\
\hline $\begin{array}{l}\text { Farmers } \\
\text { consulted } \\
\text { (survey) }\end{array}$ & 76 & 2 & 14 & 74 & 1 & 12 & 74 & 7 & 8 & 80 & 6 & 6 & 360 \\
\hline $\begin{array}{c}\text { Farmers } \\
\text { consulted } \\
\text { (FGDs) }\end{array}$ & 16 & 10 & 11 & 10 & 9 & 11 & 16 & 8 & 10 & 0 & 0 & 0 & 101 \\
\hline $\begin{array}{l}\text { Total \# of } \\
\text { farmers } \\
\text { consulted }\end{array}$ & 92 & 12 & 25 & 84 & 10 & 23 & 90 & 15 & 18 & 80 & 6 & 6 & 461 \\
\hline $\begin{array}{c}\text { \# of FGDs } \\
\text { held }\end{array}$ & 2 & 1 & 1 & 1 & 1 & 1 & 2 & 1 & 1 & 0 & 0 & 0 & 11 \\
\hline
\end{tabular}

The KIIs were used to seek expert opinions from individuals who were directly involved in the delivery of agricultural information and essential inputs. These included the vice head of the Woreda office of agriculture, the Woreda lead agronomist, and the Woreda-level representatives of the bureau of extension, social services, marketing and trade, crop production and management, cooperative promotion, as well as input supply and distribution.

The quantitative and qualitative data collected were analyzed through a gender lens using the Statistical Package for Social Scientists (SPSS) and NVIVO, respectively, and along key parameters for adoption, including essential agricultural inputs, such as access to land, labor, improved seed varieties, fertilizers, and pesticides, and critical enables, such as access to agricultural information and credit. Qualitative data were also organized along these themes and coded for additional areas of interest, including ownership, decisionmaking, access, membership, knowledge, affordability, etc. The results of the analysis are presented below.

Ethical protocols were followed throughout the data collection process. All the participants involved in the household survey, as well as those involved in the FGDs and KIIs, were voluntary and were informed that all collected information would be kept confidential. They were made aware that they should only answer questions that they are comfortable to address and that they could stop the discussion and/or interview at any time. All the individual answers were recorded as confidential information and were analyzed anonymously to be strictly used for the purpose of the study. All data were collected after verbal consent to these conditions was received from all participating individuals. No specific permissions were required from local authorities, though they were informed of the study's objectives and the plan to collect required data, and they were given copies of all proposed questions.

\section{Results and Discussion}

\subsection{Characterization of Household Heads}

Analysis of the survey data indicated that about $95 \%$ of the household heads were adult men who, on average, were about 46 years old with 5 years of formal education and 
23 years of farming experience. All household heads considered agriculture as their main source of livelihood, with only $13 \%$, mostly from a Jihur village which was closest to a major market outlet, engaging in non-farming activities.

\subsection{Endowment of Productive Inputs}

\subsubsection{Land}

The survey data showed that the average landholding for the typical sample household was $1.35 \mathrm{ha}$, which was relatively higher than the national average that ranges between 0.5 and 1 ha. However, we found differences in the average cultivated land area by male- and female-headed households, where they, on average, cultivated 1.67 and 1.3 ha., respectively, which are statistically different at the $95 \%$ confidence level. To determine the relative value of landholdings, the survey data were further analyzed by key attributes, such as the proximity to the nearest paved road, market, private and public grazing land, and water resources (Table 2). Land owned by men and women shared similar attributes, except the distance between the farmland and the nearest water bodies (lake/pond/river), which was statistically different at the confidence level of $99 \%$.

Table 2. Summary of natural capital variables against the gender of the household head.

\begin{tabular}{|c|c|c|c|}
\hline Natural Capital Variables & $\begin{array}{l}\text { Mean of Male } \\
\text { Household } \\
\text { Heads (SD) }\end{array}$ & $\begin{array}{c}\text { Mean of Female } \\
\text { Household } \\
\text { Heads (SD) }\end{array}$ & $\begin{array}{c}\text { Mean Difference } \\
\text { between Female and Male } \\
\text { Household Heads } \\
\text { (SE with } t \text {-Test Result in } \\
\text { Confidence Level) }\end{array}$ \\
\hline $\begin{array}{l}\text { Distance from farmland to the nearest } \\
\text { market }(\mathrm{km})\end{array}$ & $\begin{array}{c}5.2329 \\
(0.2013)\end{array}$ & $\begin{array}{c}6.1895 \\
(0.8027)\end{array}$ & $\begin{array}{c}0.9565 \\
(0.8738)\end{array}$ \\
\hline $\begin{array}{l}\text { Distance from farmland to the nearest } \\
\text { paved road }(\mathrm{km})\end{array}$ & $\begin{array}{c}0.8979 \\
(0.0629)\end{array}$ & $\begin{array}{c}0.7863 \\
(0.2934)\end{array}$ & $\begin{array}{l}-0.1116 \\
(0.2754)\end{array}$ \\
\hline $\begin{array}{l}\text { Distance from farmland to the nearest } \\
\text { water bodies (lake/pond/river) }(\mathrm{km})\end{array}$ & $\begin{array}{c}0.6832 \\
(0.0476)\end{array}$ & $\begin{array}{c}0.8958 \\
(0.1472)\end{array}$ & $\begin{array}{l}0.2126^{* * *} \\
(0.0458)\end{array}$ \\
\hline $\begin{array}{l}\text { Have access to livestock grazing land } \\
\qquad(\text { No }=0, \text { Yes }=1)\end{array}$ & $\begin{array}{c}0.2287 \\
(0.4206)\end{array}$ & $\begin{array}{c}0.3684 \\
(0.4956)\end{array}$ & \\
\hline Have access to cropping land $(0 / 1)$ & $\begin{array}{c}0.9912 \\
(0.0935)\end{array}$ & $\begin{array}{c}1.000 \\
(0.000)\end{array}$ & \\
\hline Size of total land holding (ha) & $\begin{array}{c}1.358 \\
(0.0385)\end{array}$ & $\begin{array}{c}1.2153 \\
(0.1258)\end{array}$ & $\begin{array}{l}-0.1427 \\
(0.1661)\end{array}$ \\
\hline Size of private grazing land (ha) & $\begin{array}{c}0.0342 \\
(0.0048)\end{array}$ & $\begin{array}{c}0.0421 \\
(0.0190)\end{array}$ & $\begin{array}{c}0.0079 \\
(0.0211)\end{array}$ \\
\hline Size of communal grazing land (ha) & $\begin{array}{c}0.2229 \\
(0.0509)\end{array}$ & $\begin{array}{c}0.3684 \\
(0.2672)\end{array}$ & $\begin{array}{c}0.1455 \\
(0.2245)\end{array}$ \\
\hline Size of cropping land (ha) & $\begin{array}{c}1.5682 \\
(0.0406) \\
\end{array}$ & $\begin{array}{c}1.2947 \\
(0.1118) \\
\end{array}$ & $\begin{array}{l}-0.2735 \\
(0.1745) \\
\end{array}$ \\
\hline $\begin{array}{l}\text { Total land area cultivated during the } \\
\text { main season (ha) }\end{array}$ & $\begin{array}{c}1.6668 \\
(0.7254)\end{array}$ & $\begin{array}{c}1.3284 \\
(0.5244)\end{array}$ & $\begin{array}{l}0.3435^{* *} \\
(0.1689)\end{array}$ \\
\hline Observations & 341 & 19 & \\
\hline
\end{tabular}

Note: ${ }^{* *}$ and ${ }^{* * *}$ indicate statistical significances at confidence levels of $95 \%$ and $99 \%$, respectively.

\subsubsection{Labor}

The average sample household was comprised of about four members. As the correlation between family size and the availability of agricultural labor can be misleading, we calculated the adult equivalent unit per household to distinguish working members from the dependents. Accordingly, we found that, on average, a household in the study area had about three adult male-equivalent members (Table 3). 
Table 3. Analysis of human capital at the household level.

\begin{tabular}{cc}
\hline Human Capital Variables: Demography & Mean (SD) \\
\hline Sex of the household (HH) head \\
Male \\
Female & $341(95 \%)$ \\
$19(5 \%)$
\end{tabular}

Note: ${ }^{a}$ We followed the conversion rates used by [33] to calculate the adult-male equivalents for members of the household who are above 15 years old.

A sex-wise comparison of the survey data revealed a statistically significant difference in the composition of male and female-headed households (Table 4). The average adult male-equivalent family size among female-headed households was lower than that of male-headed households, with direct implications on the available human capital that can support agricultural work on the family land.

Table 4. Comparison of human capital between male and female heads of households.

\begin{tabular}{|c|c|c|c|}
\hline Human Capital Variables & $\begin{array}{l}\text { Mean of Male } \\
\text { Household } \\
\text { Head (SD) }\end{array}$ & $\begin{array}{c}\text { Mean of Female } \\
\text { Household } \\
\text { Head (SD) }\end{array}$ & $\begin{array}{c}\text { Mean Difference } \\
\text { Between Female and Male } \\
\text { Household Head } \\
\text { (SE with } t \text {-Test Result in } \\
\text { Confidence Level) }\end{array}$ \\
\hline Age of the household head (years old) & $\begin{array}{l}45.5484 \\
(3.203)\end{array}$ & $\begin{array}{l}45.1053 \\
(0.6579)\end{array}$ & $\begin{array}{l}-0.4431 \\
(2.8871)\end{array}$ \\
\hline Education level of the respondent (years) & 4.5816 & 4.6842 & 0.1026 \\
\hline Household size (persons) & $\begin{array}{l}(2.1967) \\
3.5482\end{array}$ & $\begin{array}{c}(1.0789) \\
2.4211\end{array}$ & $\begin{array}{c}(0.9595) \\
-1.1271^{* * *}\end{array}$ \\
\hline No of dependent members (persons) & $\begin{array}{c}(0.0840) \\
1.5422\end{array}$ & $\begin{array}{c}(0.3089) \\
1\end{array}$ & $\begin{array}{c}(0.3591) \\
-0.5421 \text { * }\end{array}$ \\
\hline No of working members (persons) & $\begin{array}{l}(0.0670) \\
2.0492\end{array}$ & $\begin{array}{l}(0.2861) \\
1.6875 \\
\end{array}$ & $\begin{array}{l}(0.2886) \\
-0.3617 \\
\end{array}$ \\
\hline Adult male equivalent unit & $\begin{array}{c}(0.0587) \\
2.9552\end{array}$ & $\begin{array}{c}(0.1983) \\
1.9905\end{array}$ & $\begin{array}{c}(0.2684) \\
-0.9646^{* * *}\end{array}$ \\
\hline Observations & $\begin{array}{c}(1.3534) \\
341\end{array}$ & $\begin{array}{c}(1.2403) \\
19\end{array}$ & $(0.3179)$ \\
\hline
\end{tabular}

Note: ${ }^{*}$ and ${ }^{* * *}$ indicate statistical significances at confidence levels of $90 \%, 95 \%$, and $99 \%$, respectively.

\subsection{Productive Resources}

Looking at the intra-household distribution of resources, most of the productive resources, including cattle, small ruminants, farm tools, and cash savings, were owned by men. Women's possessions were mainly limited to the dairy products they make, poultry, and the small amount of cash gained from selling their products. The power relation and decision-making structure followed this hierarchy in ownership, giving the man autonomy on key decisions, including land ownership and rentals, the purchase or sale of animals, types of crops to grow, choices of agronomic practices, and application of essential agricultural inputs. Women mainly made decisions on the purchase of consumable 
goods, and marketing of goods, such as firewood, food, and drinks that do not generate substantial income.

Analysis of the survey data showed that, on average, a household owned 3 cattle with a maximum of 12 per household, 4 sheep with a maximum of 31 per household, 2 equines with a maximum of 11 , and 4 poultry with a maximum of 100 . To make the comparison easier, we also computed the average number of livestock owned to be six tropical livestock units (TLU). While this could be considered good, only $24 \%$ of the households had access to grazing land, and most relied on a cut-and-carry system to feed their livestock.

\subsection{Gender Roles}

The survey results showed that both men and women engaged in agricultural activities, but with a clear division of labor. In $100 \%$ of the cases, men were primarily responsible for the overall management of crop lands, including tillage with oxen-drawn implements, broadcast seeding, wheat harvesting, and threshing. Women were responsible for raised bed preparation, fertilizer micro dosing, poultry, grain processing, and gardening for their own consumption and sale. Though at varying levels by household and by activity, both women and men participated in weeding (at least 30\% women), harvesting (at least $29 \%$ women), livestock management (at least $43 \%$ women), diary processing (at least $79 \%$ women), and marketing of produce (at least $60 \%$ women).

\subsection{Adoption of Improved Technologies}

\subsubsection{Improved Varieties}

Lentil is the main legume crop grown in the study area. During the main agricultural season of 2017, lentil was cultivated on $37 \%$ of the plots/household, with an average of 0.6232 ha dedicated to its production either as a main or associated crop, and an area share of $37 \%$ per household (Table 5). There was no statistically significant difference in the average lentil area among male and female-headed households. The production of lentil in rotation with wheat was widely practiced by $92 \%$ of the sample farmers, while only $5 \%$ produced it in association with teff.

Table 5. Cereal legume association.

\begin{tabular}{ccccc}
\hline Crop for Cereal-Legume & Freq. & Percent & Valid & Cum. \\
\hline Teff-lentil & 18 & 5.00 & 5.00 & 5.00 \\
\hline Wheat-lentil & 332 & 92.22 & 92.22 & 97.22 \\
\hline Sorghum-lentil & 1 & 0.28 & 0.28 & 97.50 \\
\hline Wheat-Faba bean & 7 & 1.94 & 1.94 & 99.44 \\
\hline Wheat-field pea & 1 & 0.28 & 0.28 & 99.72 \\
\hline Teff-Haricot bean & 1 & 0.28 & 0.28 & 100.00 \\
\hline Total & 360 & 100.00 & 100.00 & \\
\hline
\end{tabular}

The survey results showed that $98 \%$ of surveyed farmers had used the Alamaya improved variety Alamaya at least in one of their plots. The difference in the use of improved lentil varieties among male and female-headed households was not statistically significant. About $35 \%$ of farmers reported that they practiced cereal-legume association by keeping similar cereals and legumes over time, while $65 \%$ reported that they changed the cereals associated with legumes. Irrespective of the changes in the association, $98 \%$ of the farmers reported an increase in yield when rotation was applied continuously.

All sample farmers (irrespective of age and sex) explained that, though people still preferred the taste of the local variety, Alamaya offered a much greater yield, especially when grown in rotation with other cereals, required less inputs (fertilizer and pesticide), and fetched a much higher price in the market. 


\subsubsection{Fertilizers, Herbicides, and Pesticides}

The analysis of the household survey data indicated that $95 \%$ of households used chemical fertilizers, pesticides, insecticides, and herbicides. However, variations in the amount and type of fertilizer applied were noted, with lower use of Urea and NPS (compound Nitrogen-Phosphate-Sulphur fertilizer) among female-headed households. Though the use of crop residue as a natural fertilizer was still practiced in the community, almost $100 \%$ of the respondents noted that they increasingly used it as animal feed, with no difference between male and female respondents. While $98 \%$ and $100 \%$, respectively, of male and female households used herbicides, $96 \%$ and $100 \%$, respectively, of male and female-headed households used pesticides.

\subsection{Agricultural Information and Credit}

The survey data showed that extension agents were the main source of agricultural information in the study area, mainly targeting household heads $(82.2 \%)$, and, at times, both the household head and spouses (9.4\%). In the remaining $8.4 \%$ of the cases, spouses or children were targeted. Unfortunately, only $44.4 \%$ of the farmers rated the quality, timeliness, and relevance of the extension information they received as good or very good while $44.1 \%$ rated it as moderate, and the remaining $11.5 \%$ as poor or very poor.

All eligible male and female members of the household could be members of credit associations. In the case of $59 \%$ of our sample households, at least one member of the family was a member in at least one credit association. Our results showed that mostly (in $57.3 \%$ of these households) young male and female members of the households were the ones to seek membership in credit associations, with an almost equal share between male and female youth.

\section{Discussions}

We combined the survey findings with qualitative data collected through FGDs and KIIs to examine if there were gender-based differences in the adoption of improved legume varieties between men, women, and youth, and what could be done to promote large-scale and equitable adoption. We focused our assessment on key determinants of agricultural technology adoption, including farmers' access and control over essential agricultural inputs, including land and labor; the adoption of improved technologies, including fertilizers and pesticides; access to information and credit; and the combined effect on the adoption of selected legume varieties [18-23].

\subsection{Gender Roles}

Men and women in Ethiopia hold different positions in relation to farming. The concept of a 'farmer' is based on a cultural and symbolic construction of a masculine subject, where men do the real farming and women only take part as caretakers [34]. The survey results, though dominated by the male perspective, also reflected this sentiment by categorizing most of their contributions under 'supporting or joint roles'. Discussions with married women revealed similar conceptualizations, where they referred to the man as the 'farmer', a title ascribed to the individual responsible for plowing the land with oxen and planting, tasks that are culturally prescribed to and primarily performed by men. The title also gives the man decision-making authority.

The case was different for women heads of households (widows and wives of migrant laborers), who took on more responsibilities themselves or hired the help they need to get the work done. Even though the male-prescribed activities were still performed by hired men or male relatives, the women were still accepted as 'farmers' commensurate to their decision-making role and the responsibilities they carried to manage the farm.

\subsection{Asset Ownership}

Rural women in the developing world, including Ethiopia, rarely have the same level of access and control over resources as their male counterparts [35,36]. Our results 
(Table 2) show that ownership of farmland is also male dominated [37]. The same was confirmed both through the survey results and the FDGs, which indicated that most of the household's productive resources, including livestock, small ruminants, farm tools, and cash savings, were owned by men. Married women's possessions were mainly limited to the dairy products they made, poultry, and the small amount of cash gained from selling their products.

FGDs with male (young and old) and female farmers showed that the power relation and decision-making structure followed this hierarchy in ownership, giving men autonomy on key decisions, including land ownership and rentals, the purchase or sale of animals, types of crops to grow, and choices of agronomic practices and application of essential agricultural inputs. Women made decisions on the purchase of consumable goods and marketing of goods, such as firewood, food, and drinks, that do not generate substantial income. However, both women and young men had fewer assets compared to adult males, who were more established and had accumulated assets.

\subsubsection{Land}

Land is an essential, yet very scarce, natural capital in rural Ethiopia. Though women have the legal right to own land-either through inheritance or as a widow-traditional norms dictated that family land should be distributed among sons to keep the property within the family and avoid the loss of land to in-laws. This trend is gradually changing in the region due to the 1991-1996 land redistribution policy and the land registration program of October 2004, which secured women's right to own land [38]. However, cultural norms continue to influence decisions at the community and household levels.

With the growing population, land fragmentation continues to pose a serious threat to agricultural productivity in Ethiopia [39]. The average land holding per household continues to decline as does the availability of communal grazing areas. Many of the youth in the study area thus rent land located far from their residential area and, at times, of marginal quality, thereby reducing their profit margin. The youth explained that they usually work as daily laborers (construction work), in contract farming, sheep breeding, and selling chicken or eggs to supplement their income.

Despite the scarcity of arable land, the collected data indicated that the total area cultivated as a percentage of total land owned was lower among female farmers than their male counterparts (Table 2). The women explained that this was due to the high cost of production for female farmers, who have greater demand for labor and have relatively lower knowledge and bargaining power to purchase agricultural inputs from the private sector. In line with the customary division of labor, it is considered inappropriate for women to plow land [40].

\subsubsection{Labor}

Though most of the work is performed by members of the household, hiring additional labor is also a common practice, because, as shown in Tables 3 and 4, the adult male equivalent per family is only 2.9 , which may not be sufficient during the peak-labordemand seasons. We found that male-headed households mainly hired laborers during land preparation, fertilizer application, spraying chemical inputs, and harvesting. In addition to these, women heads of households explained that they must also hire laborers to help with planting, threshing (for wheat and teff), and storing or loading produce to take to the market.

Hiring daily laborers is, however, very costly. The women explained that, on average, they paid 250-300 birr/day for harvesting, 600 birr/day for land preparation if using his own plow and oxen-if not, about 300 birr/day-and 250-300 birr/day for threshing. Hiring laborers for many tasks substantially increases women's cost of production; therefore, whenever possible, women negotiate alternative payment mechanisms, such as exchange of labor services or produce. Women could also offer comparable services, such as preparation of raised beds, where they follow behind the farmer and manually pile the soil to create the 
beds, fertilizer application (micro-dosing), and weeding; or allow the laborer to take the crop residues. The youth explained that working on women's fields is an important source of income that helps them sustain their livelihoods and support their families.

\subsection{Adoption of Improved Technologies}

Sustainable and effective adoption of new agricultural technologies and practices is essential to increasing productivity and income. The adoption rate, however, depends on their timely, adequate, and consistent availability and accessibility.

\subsubsection{Fertilizers and Pesticides}

Fertilizers and pesticides are essential inputs required to increase agricultural productivity, and their use by Ethiopian smallholder farmers is on the rise [41]. This is consistent with the high (95\%) level of use of chemical fertilizers, pesticides, insecticides, and herbicides we found in our survey data. In terms of pesticide application, farmers indicated that they heavily rely on its use to remove rampant pests and weeds. Farmers explained that they mainly access these inputs through the agricultural cooperatives that bear the burden of the cost associated with storage, transportation, and administration [42]. The input delivery system also allows the extension system to control prices and the quality of the products, and provide information on their use.

However, all discussants from the FGD (irrespective of age and sex) revealed that the amounts of fertilizers and pesticides that are brought by the cooperatives are neither timely nor enough to meet local demand. Therefore, most farmers are forced to buy their chemical inputs from the private sector. Female heads of households emphasized their preference for cooperatives, as the purchase comes with advisory services, better quality, and lower prices. The cooperatives also facilitate credit, which makes it easier for them. Older and younger men, though they also prefer to purchase their chemical inputs from the cooperatives, they were less apprehensive about direct purchases from the private sector as they have better access and awareness of market conditions, and are more experienced in price negotiation.

The KIIs with Woreda agricultural bureau and extension service representatives indicated that the delivery of fertilizer and pesticides to farmers is a very complex process. We learned that, when cooperatives bring the inputs, the private traders intentionally reduce their prices to be lower than the price offered by the cooperatives to entice the farmers to buy them from them. When the cooperatives bring smaller amounts because farmers are not buying them, then they inflate the price as soon as the cooperatives run out of inputs, making it extremely difficult for farmers to buy and apply enough fertilizers and pesticides to their fields. It was noted from the discussion that the price of chemicals in private shops could go as high as triple the price set by the cooperatives. In such cases, farmers use less than the recommended amounts, which exposes them to further infestation with invasive weeds and pests.

The lack of an advisory service on how to mix and use the fertilizers and pesticides was a serious concern raised by all. We learned that, though the traders might have the knowledge and certificate to sell these inputs, the shop managers often do not and cannot give proper guidance to farmers. We found that the youth had better chances of obtaining the needed information and teaching themselves the chemical application procedure through reading pamphlets, searching the internet, or using mobile call-ins for extension services than the older men and women heads of households.

The comparison of the responses from male, female, and young farmers during the FGDs showed no difference in the access to these inputs from the cooperatives. However, differences were noted in their abilities to access these inputs from the private sector. For women farmers, purchasing the chemical inputs from the market at a higher price, coupled with the lack of guidance on how to use them and the added cost of labor, presented a higher risk and challenge and compromised their profit margin. The youth also faced similar challenges as they already farm on rented land, which further elevates their total cost of production. 


\subsubsection{Seeds of Improved Varieties}

Seed security, which includes adequate availability and accessibility of seeds, is a prerequisite for increasing food production, income, and ensuring food security [43]. Improved varieties that are adapted to context-specific biotic and abiotic stresses are invaluable in boosting agricultural productivity, especially when combined with appropriate agronomic practices. The Ethiopian seed system currently relies on inefficient government-led institutions, as well as formal and informal private businesses [44]. Effective use of seeds also depends on access to fertilizers and knowledge of good agronomic practices.

\section{Lentil and Chickpea Seed Development}

Lentil and chickpea are customarily planted in the Ethiopian highlands during the main rainy season of July and August, and are commonly grown in association with wheat and teff (Table 5). However, this creates moisture stress for the plant during their flowering stage, which occurs towards the end of September, thereby reducing the crop's productivity. There is thus great demand for varieties that are early maturing, disease resistant, and adaptable to local conditions. Studies have also documented the fact that local varieties are low yielding and prone to disease, resulting in low productivity per unit area, and low grain quality with small seeds, undesired color, and low plumpness [15,30].

According to the Woreda office of agriculture, the Alamaya lentil variety was developed and initially introduced to the region some 10 years ago by the Debirezeit agricultural research center. The initial dissemination of the variety was mainly farmer-led, where farmers exchanged the seed amongst themselves. Since then, they have been promoted for large-scale adoption through the agricultural extension system. Similarly, several improved chickpea varieties were introduced to the study area, including Habru', 'Arerti', 'Mastewal', and 'Natoli'. 'Habru', and 'Arerti', which are Kabuli-type chickpea varieties, and 'Mastewal' and 'Natoli', which are desi types. Farmers particularly preferred the Kabuli chickpea varieties. The KIIs further revealed that the key challenge lies in the lack of an established seed replacement and supply system that ensures seed standardization, packaging, labeling, and timely distribution.

\section{Alamaya Lentil-Essential Cash Crops}

Discussions with male, female, and youth farmers confirmed that the Alamaya variety was introduced to their community by the agricultural extension system, through agricultural cooperatives, Agricultural Research Institutes, and, to a lesser extent, 'Farmers' Seed Production Associations. Alamaya was preferred for its pest-resistant trait, the high yield it delivered, and its ability to grow on marginal land. The variety was introduced at a time when the local landrace (black lentil) was severely hit by a disease locally known as wag, which further accelerated the rate of adoption of the new Alamaya variety.

During our FGDs, we found that most farmers grew this lentil variety as a cash crop to generate the funds required to purchase enough fertilizers to grow wheat and teff, which require large quantities of chemical inputs but do not generate sufficient profit to sustain their production. The variety also produces more residue (as compared to wheat) that is soft and salty, and is thus preferred by livestock. Farmers explained that, with annual increases in input prices, it makes economic sense to shift to mono-cropping lentil without rotation. This confirms other findings that also identified the unavailability of seeds of improved varieties as constraints to legume-based rotations [17]. More than three-fourths of the farmers who participated in the FGD reported that they have been growing Alamaya lentil variety consecutively for the past 3-4 years. However, with the lack of adequate and timely access to improved seed varieties, farmers relied on recycled seeds, which, according to them, yield less and less with every additional year of re-use.

\section{Kabuli Chickpea}

According to the Woreda representative of agriculture, Kabuli chickpea was introduced to the area in 2008 by the agricultural extension system and through agricultural 
cooperatives. By 2010, it was widely disseminated in the Woreda and, per the recommendation of the agricultural extension system, it was grown in rotation with teff and wheat. Farmers recalled that the variety was highly appreciated for its high productivity, its larger size as compared to the local variety, its contribution to soil fertility, low demand for agricultural inputs, and the ability of farmers to use the residue as fodder for their animals. However, we found that the share of chickpea grown in the study area decreased over time to an almost negligible amount, with an average of 0.007 (0.437 SD) area of land dedicated to its production either as a main or associated crop, and a total area share of 0.0036 (0.0218SD) during the main season [28]. The FGDs revealed that this was mainly due to cultural norms that encouraged passer-by foraging and the low price in the local market.

Cultural norms dictate that passers-by and the hungry should be allowed to consume the green chickpea straight off the fields. However, some take this norm to mean free and unlimited access to the fields and take large quantities, leaving the farmer with little to sell or use for their own consumption. This issue was raised by all discussants in the FGDs, irrespective of age and sex, except for those from Jihur village. who mobilized themselves into clusters (cluster farming) to minimize exposure to plunder and to share the burden of keeping watch over their fields. When asked why the other villages do not do the same, the respondents explained that they did not have the support of the extension agents to mobilize. The youth also explained that it is particularly difficult for them to mobilize in clusters as their fields are scattered in different places.

The second challenge was related to marketing. Farmers explained that many people still preferred the taste of the local variety. Farmers were thus unable to secure a high price for their produce, especially as compared to lentil. As subsistence farmers who are risk-avert and intent on generating as much income off their land as they can, farmers choose to grow lentil over chickpea.

\section{Seed Delivery System}

Farmers identified inefficient agricultural cooperatives as the main bottleneck in the current seed delivery system, as they fail to collect and collate farmers' demand for seed variety and timely communicate the same to Woreda-level administrations. Farmers of all ages and sexes complained that the seeds rarely arrived in time for the planting season, and rarely in a sufficient quantity. Farmers thus resorted to either reusing their own seeds or bartering other commodities with those who have them. However, recycling seeds repeatedly reduces their germination and potency, stunts growth, makes them vulnerable to pests and diseases, decreases their productivity, and even entails adverse health effects on consumers $[45,46]$. These were also observed in the field and confirmed by the farmers, who reported that the harvest during the $2017 / 2018$ season was very low due to the increased occurrence of crop diseases, jeopardizing their livelihoods.

\subsection{Agricultural Information and Credit}

5.4.1. Agricultural Information

Extension Services

Adequate and timely access to information is an essential first step to the effective and sustainable adoption of technologies. In Ethiopia, the extension service plays a prominent role in information dissemination and improving the adoption of agricultural technologies [47]. Analysis of the household surveys also indicated that extension agents were the main source of agricultural information in the study area. According to the KII held with the Woreda representative of the Bureau Agricultural Extension, information was relayed through field demonstration, targeted training, agricultural cooperatives, distribution of posters and pamphlets, media broadcasts (e.g., television and radio programs), peer-to-peer learning facilitated through the organization of farmers into development groups locally known as 'limat budin', information sharing between neighbors and friends, and through 
the private sector-particularly input traders. The limat budin are claimed to be economical and effective to deal with the increasing demand for extension agents.

Another strategy devised by the extension system was to divide the population into early adopters, mid-adopters, and laggards, and to address the specific needs of each group accordingly [48]. However, there were not enough extension agents to provide such a level of targeted service. Hence, the focus continued to be on 'early adopters', effectively leaving the laggards and other marginalized groups behind. Interviews held with Woreda-level extension representatives indicated that women tended to adopt recommended packages better than men. The administration had thus instituted a quota system to encourage women's participation in all of their extension efforts. According to the quota, $30 \%$ of the participants in training should be women. However, this has been a difficult goal to reach, as participation in such events is customarily assigned as a man's role. Training is also organized at the Woreda and kebele levels and requires a lot of time to attend.

\section{Gender-Based Differences in Access to Information}

During the FGD, comparison across the sexes revealed that men had greater access to information than women. Men have greater opportunities to attend field demonstrations, targeted training/workshops that can take several hours or even days, depending on the topic covered, represent their household in a 'limat buden' and community meetings, and have greater opportunities to see posters or receive pamphlets as they go to town more frequently than women. The youth also attested that they were less likely to attend field demonstrations, targeted training/workshops, or be a part of the 'limat buden' and community meetings because they grow their crops on rented land that is often located far from the center of the village where the gatherings and training occur, and they rarely represent the household in community gatherings. However, we found that they were the greatest consumers of information shared through posters and pamphlets, as they were better educated than the older men and women.

We learned that the youth also accessed information through fast dial \#884-a 'calling service' established to obtain agricultural advisory services. This service was also used by a few of the older men. However, the women complained that they had little access to such information, as most did not own cell phones. This was confirmed by the household survey, where $91 \%$ of the male heads of household reported that they owned a mobile phone compared to less than $15 \%$ ownership among women.

Discussions with women groups revealed distinct differences between married women and women heads of households. While married women expressed difficulty accessing information through the traditional extension system, women heads of households were proud to report that they attended as much training as they could and rarely missed any opportunity to learn about new technologies and improved farming practices because they could not afford to lose their crops.

\subsubsection{Credit}

Credit is an essential service that facilitates the adoption of improved agricultural practices, especially for subsistence farmers who have limited access to income before harvest [49]. According to the KIIs held with the Woreda Administration, the most common criteria for credit in rural areas is land ownership. The main credit provider was identified as the Amhara Credit and Saving Institution (ACSI) - a state-owned financial intermediary, which offers farmers credit at a very high interest rate of $17-20 \%$. ACSI is available for all and makes no distinction between male and female farmers. Farmers (irrespective of age and sex) explained that they mainly borrowed money to purchase fertilizers that were either supplied through the agricultural cooperatives or through the private sector.

\section{Conclusions}

Sustainable adoption of improved technologies is a process and requires the establishment of systems that ensure its continued availability, accessibility, and adaptability to fit 
evolving local conditions and equitably meet the needs of all actors in a community. In this study, we sought to understand the differential challenges to, and opportunities for, large-scale adoption of Alamaya lentil and Kabuli chickpea varieties in the study area by considering key parameters that collectively influence one's access to essential agricultural technologies.

We learned that, in addition to its contribution to soil fertility, all farmers (irrespective of sex and age) were especially interested in growing Alamaya lentil as a cash crop to generate sufficient income to support cereal (wheat and teff) production, secure household food security, and sustain their livelihoods. Annual increases in input prices have made cereal production - which requires large quantities of chemical inputs-an unprofitable undertaking. Farmers are thus forced to subsidize its production from other sources to sustain household food security.

We found that the main challenge lies in the seed supply system, which has failed to sufficiently and timely meet the demand. The study also identifies many other challenges within the agricultural system that currently seem less influential, but are detrimental to the large-scale and equitable adoption of the legume varieties. This study demonstrates that equal availability of opportunities does not mean equal accessibility and that these factors are not gender neutral, but present differential challenges to men, women, and youth farmers in the area who have differential access to land, labor, farm implements, agricultural information, credit, and operate within cultural biases that limit their effective participation in the sector. Unabated, these challenges will continue to reinforce existing gender-based constraints and unfairly limit the youth and especially female heads of households from accessing essential agricultural information, and credit that is mainly used to purchase the essential fertilizers and pesticides required to adopt seeds of improved varieties. The increased cost of inputs will also limit their ability to hire additional labor. As it stands, the percentage of cultivated land owned by women is lower than men, and they have less livestock and other farming implements and assets.

We also showed intra-gender differences, where female heads of household were able to take advantage of the extended detailed training as they were in control of their own time, while married women could not. Cultural norms and marketing challenges were also identified as specific additional barriers to the adoption of Kabuli chickpea varieties in the study area.

The study also reveals that, in the absence of a well-structured system that ensures timely and equitable access to key services and essential inputs, farmers, as profit maximizers, will adapt their ways to maximize profit. However, in so doing, they abandon good agronomic practices, such as crop rotation and application of the recommended doses of fertilizers and pesticides. This was evident in the farmers' acknowledgment of recycling seeds, using less chemical inputs than the recommended amount to keep it affordable, applying fertilizers and pesticides of questionable quality to address short-term challenges posed by growing pests and diseases, and, in some cases, resorting to growing older local varieties. These in turn reduce the overall productivity and household income and nutrition, with potential implications on land degradation, depending on the type and quantity of the chemical inputs used.

Our findings support previous studies that emphasized the role of gender in influencing the propensity to adopt agricultural technologies, and highlights the importance of a systemic approach to comprehensively address the identified gender-based challenges and establish an efficient gender and age-sensitive seed system that: (i) sufficiently links research to development by delivering research outputs both in the form of improved seeds and related agronomic practices through a gender-sensitive and multi-faceted extension advisory system, (ii) establishes a sustainable seed replacement and supply system complete with standardization and geared for timely, adequate, and equitable distribution, (iii) avails credit opportunities at affordable interest rates and alternative collateral requirements to accommodate the different socio-economic groups represented in society, and (iv) encourages the engagement of the private sector under clear guidelines that ensure strict monitoring 
of the quality of chemical inputs supplied to the market, protects consumers from price extortion, and offers sufficient information for their use.

Author Contributions: Conceptualization, B.D.; methodology, B.D. and W.A.; software, B.D. and W.A.; validation, B.D., W.A., A.T. and Q.B.L.; formal analysis, B.D. and W.A.; investigation, B.D., W.A. and A.T.; resources, Q.B.L.; data curation, B.D. and W.A.; writing - preparation, B.D.; writing-review and editing, B.D., W.A., A.T. and Q.B.L.; visualization, B.D. and A.T.; supervision, Q.B.L. and B.D.; project administration, Q.B.L.; funding acquisition, Q.B.L. All authors have read and agreed to the published version of the manuscript.

Funding: This research was funded by the CGIAR Program on Grain Legumes and Dryland Cereals (GLDC) grant number [200125]. And the APC was funded by the same project.

Institutional Review Board Statement: As the ICARDA IRB board was only established in July 2019, while our data was collected in 2018. The data used in the study was thus collected in consultation with, and approval from the (local) Debre Birhan Agricultural Research Center (DBARC) which directly reports to the (regional) Amhara Region Agricultural Research Institute (ARARI). The Institute holds the legal mandate to conduct and coordinate research in the mandate area. A letter from the Institute confirming their review of questions used for data collection and their clearance allowing us to collect required data was submitted to the Journal on 3 December 2021 and was accepted prior to the review of our paper.

Informed Consent Statement: All the participants involved in the household survey, as well as those involved in the FGDs and KIIs, were voluntary and were informed that all collected information would be kept confidential. They were made aware that they should only answer questions that they are comfortable to address and that they could stop the discussion and/or interview at any time. All the individual answers were recorded as confidential information and were analyzed anonymously to be strictly used for the purpose of the study. All data were collected after verbal consent to these conditions was received from all participating individuals.

Data Availability Statement: The data presented in this study are available on request from the corresponding author. The data are not publicly available due to the personal and private nature of the data.

Conflicts of Interest: No potential financial or other conflict of interest were reported by the authors.

\section{References}

1. Kusmintarti, A.; Thoyib, A.; Ashar, K.; Maskie, G. The relationships among entrepreneurial characteristics, entrepreneurial attitude, and entrepreneurial intention. IOSR J. Bus. Manag. 2014, 16, 25-32. [CrossRef]

2. Nuthall, P. Modelling the origins of managerial ability in agricultural production. Aust. J. Agric. Resour. Econ. 2009, 53, 413-436. [CrossRef]

3. Knowler, D.; Bradshaw, B. Farmers' adoption of conservation agriculture: A review and synthesis of recent research. Food Policy 2007, 32, 25-48. [CrossRef]

4. $\quad$ Rogers, E.M. Diffusion of Innovations, 3rd ed.; Free Press: New York, NY, USA, 1983.

5. Conley, T.G.; Udry, C.R. Learning about a New Technology: Pineapple in Ghana. Am. Econ. Rev. 2010, 100, 35-69. [CrossRef]

6. Neill, S.; Lee, D.R. Explaining the Adoption and Disadoption of Sustainable Agriculture: The Case of Cover Crops in Northern Honduras. Econ. Dev. Cult. Chang. 2001, 49, 793-820. [CrossRef]

7. Feder, G.; Umali, D.L. The Adoption of Agricultural Innovations: A Review. Technol. Forecast. Soc. Chang. 1993, 43, $215-239$. [CrossRef]

8. Adesina, A.A.; Baidu-Forson, J. Farmers' perceptions and adoption of new agricultural technology: Evidence from analysis in Burkina Faso and Guinea, West Africa. Agric. Econ. 1995, 13, 1-9. [CrossRef]

9. Lee, D.R. Agricultural Sustainability and Technology Adoptions: Issues and Policies for Developing Countries. Am. J. Agric. Econ. 2005, 87, 1325-1334. [CrossRef]

10. Mendola, M. Agricultural technology adoption and poverty reduction: A propensity-score matching analysis for rural Bangladesh. Food Policy 2007, 32, 372-393. [CrossRef]

11. Geda, S.A.; Kuhl, R. Exploring Smallholder Farmers' Preferences for Climate-Smart Seed Innovations: Empirical Evidence from Southern Ethiopia. Sustainability 2021, 13, 2786. [CrossRef]

12. Guo, Q.; Ola, O.; Benjamin, E.O. Determinants of the Adoption of Sustainable Intensification in Southern African Farming Systems: A Meta-Analysis. Sustainability 2020, 12, 3276. [CrossRef] 
13. Yigezu, Y.A.; Bishaw, Z.; Niane, A.A.; Alwang, J.; El-Shater, T.; Boughlala, M.; Aw-Hassan, A.; Tadesse, W.; Bassi, F.P.; Amri, A.; et al. Institutional and farm-level challenges limiting the diffusion of new varieties from public and CGIAR centers: The case of wheat in Moroccan. Food Secur. 2021, 13, 1359-1377. [CrossRef]

14. Dessalegn, B.; Kassam, S.; Ludgate, N.; Al Ulayyan, A. Technology tracking: Understanding decisions to adopt, not to adopt, and dis-adopt household greywater filtration systems. J. Agric. Ext. Rural. Dev. 2018, 10, 134-143. [CrossRef]

15. Chichaybelu, M.; Nigusie, G.; Fikre, A.; Gemechu, B.; Mekuriaw, T.; Geleta, T.; Chiche, W.; Rubyogo, J.-C.; Akpo, E.; Ojiewo, C.O. Enhancing Chickpea Production and Productivity Through Stakeholders' Innovation Platform Approach in Ethiopia. In Enhancing Smallholder Farmers' Access to Seed of Improved Legume Varieties Through Multi-Stakeholder Platforms; Akpo, E., Ojiewo, C.O., Kapran, I., Omoigui, L.O., Diama, A., Varshney, R.K., Eds.; Springer: Singapore, 2021. [CrossRef]

16. Bailey-Serres, J.; Parker, J.E.; Ainsworth, E.A.; Oldroyd, G.E.D.; Schroeder, J. Genetic strategies for improving crop yields. Nature 2019, 575, 109-118. [CrossRef] [PubMed]

17. Yigezu, Y.A.; El-Shater, T.; Boughlala, M.; Bishaw, Z.; Niane, A.A.; Maalouf, F.; Degu, W.T.; Wery, J.; Boutfiras, M.; Aw-Hassan, A. Legume-based rotations have clear economic advantages over cereal monocropping in dry areas. Agron. Sustain. Dev. 2019, 39, 58. [CrossRef]

18. Diiro, G.M.; Ker, A.P.; Sam, A.G. The role of gender in fertilizer adoption in Uganda. Afr. J. Agric. Resour. Econ. 2015, 10, 117-130. [CrossRef]

19. Gaya, H.I.; Tegbaru, A.; Bamire, A.S.; Abdoulaye, T.; Kehinde, A.D.A. Gender differentials and adoption of drought tolerant maize varieties among farmers in northern Nigeria. Eur. J. Bus. Manag. 2017, 9, 81-87.

20. Kassa, Y.; Kakrippai, R.; Legesse, B. Determinants of adoption of improved maize varieties for male headed and female-headed households in West Harerghe zone, Ethiopia. Int. J. Econ. Behav. Organ. 2013, 1, 33-38. [CrossRef]

21. Peterman, A.; Behrman, J.; Quisumbing, A. A review of empirical evidence on gender differences in non-land agricultural inputs, technology, and services in developing countries. IFPRI 2010, Discussion Paper 00975. Available online: https://www.fao.org/3/ am316e/am316e.pdf (accessed on 28 November 2021).

22. Doss, C. Women and agricultural productivity: What does the evidence tell us? Econ. Growth Cent. Discuss. Pap. 2015, Discussion Paper 1051, Economic Growth Center (EGC), Yale University. Available online: https:/ / elischolar.library.yale.edu/egcenterdiscussion-paper-series/1059 (accessed on 18 October 2021).

23. Doss, C.; Morris, M. How Does Gender Affect the Adoption of Agricultural Innovations? The Case of Improved Maize Technology in Ghana. Agric. Econ. 2001, 25, 27-39. [CrossRef]

24. Wendimu, G.Y.; Moral, T.M. The Challenges and Prospects of Ethiopian Agriculture. Cogent Food Agric. $2021,7,1923619$. [CrossRef]

25. Ojiewo, C.; Rubyogo, J.C.; Wesonga, J.; Bishaw, Z.; Abang, M.; Gelalcha, S. Legume variety development, release and promotion for adoption. In Mainstreaming Efficient Legume Seed Systems in Eastern Africa; Food and Agriculture Organization of the United Nations: Addis Ababa, Ethiopia, 2018; ISBN 978-92-5-121018-2. [CrossRef]

26. Erana, K. Grain legumes production and productivity in Ethiopian smallholder agricultural system, contribution to livelihoods and the way forward. Cogent Food Agric. 2020, 6, 1722353. [CrossRef]

27. CSA. Agricultural Sample Survey 2017/18, Report on Farm Management Practices (Private Peasant Holdings, Meher Season); CSA: Addis Ababa, Ethiopia, 2018.

28. CSA. Agricultural Sample Survey 2017/18 (2010 E.C.), AREA and Production of Major Crops (Private Peasant Holdings, Meher Season); CSA: Addis Ababa, Ethiopia, 2018.

29. Merga, B.; Haji, J. Economic importance of chickpea: Production, value and world trade. Agric. Plant Sci. 2019, 5, 1615718. [CrossRef]

30. Yirga, C.; Rashid, S.; Behute, B.; Lemma, S. Pulses value chain potential in Ethiopia: Constraints and opportunities for enhancing exports. Gates Open Res. 2019, 3, 276. [CrossRef]

31. Stagnari, F.; Maggio, A.; Gailien, A.; Pisante, M. Multiple benefits of legumes for agricultural sustainability: An overview. Chem. Biol. Technol. Agric. 2017, 4, 2. [CrossRef]

32. Chambers, R.; Conway, G. Sustainable Rural Livelihoods: Practical Concepts for the 21st Century; Discussion Paper; Institute of Development Studies: Brighton, UK, 1992.

33. Waid, J.L.; Bogard, J.R.; Thilsted, S.H.; Gabrysch, S. Estimates of Average Energy Requirements in Bangladesh: Adult Male Equivalent Values for Use in Analyzing Household Consumption and Expenditure Surveys. Data Brief 2017, 14, 101-106. [CrossRef]

34. Gella, A.A.; Tadele, G. Gender and Farming in Ethiopia: An Exploration of Discourses and Implications for Policy Research Working Paper 084 Future Agricultures. Ethiop. J. Soc. Sci. Humanit. 2015, 11, 1-28.

35. Doss, C.; Kim, S.M.; Njuki, J.; Hillenbrand, E.; Miruka, M. Women's Individual and Joint Property Ownership Effects on Household Decision-Making; Discussion Paper No. 01347; International Food Policy Research Institute: Washington, DC, USA, 2014. Available online: http:/ / ebrary.ifpri.org/cdm/ref/collection/p15738coll2/id/128149 (accessed on 10 October 2021).

36. Galiè, A.; Mulema, A.; Benard, M.A.M.; Onzere, S.N.; Colverson, K.E. Exploring gender perceptions of resource ownership and their implications for food security among rural livestock owners in Tanzania, Ethiopia, and Nicaragua. Agric. Food Secur. 2015, 4, 2. [CrossRef] 
37. Fafchamps, M.; Quisumbing, A.R. Control and ownership of assets within rural Ethiopian Households. J. Dev. Stud. 2002, 28, 47-82. [CrossRef]

38. Leta, T.B.; Berlie, A.B.; Ferede, M.B. Effects of the current land tenure on augmenting household farmland access in South East Ethiopia. Humanit. Soc. Sci. Commun. 2021, 8, 35. [CrossRef]

39. Paul, M.; Githinji, M. Small farms, smaller plots: Land size, fragmentation, and productivity in Ethiopia. J. Peasant. Stud. 2017, 45, 757-775. [CrossRef]

40. Teklu, A. Land Degradation and Women's Rights in Amhara Region, Ethiopia; Research Report 4; Russell Press: Nottingham, UK, 2005; Available online: https:/ / pubs.iied.org/sites/default/files/pdfs/migrate/12521IIED.pdf (accessed on 23 September 2021).

41. Assefam, B.T.; Reidsma, P.; Chamberlin, J. Farm- and community-level factors underlying the profitability of fertilizer usage for Ethiopian smallholder farmers. Agrekon 2021, 60, 460-479. [CrossRef]

42. Rashid, S.; Tefera, N.; Minotaand, N.; Ayele, G. Can modern input use be promoted without subsidies? An analysis of fertilizer in Ethiopia. Agric. Econ. 2013, 44, 595-611. [CrossRef]

43. Bishaw, Z.; Gastel, A.R.T. ICARDA's Approach to Seed Delivery in Less Favorable Areas Through Village-Based Seed Enterprises: Conceptual and Organizational Issues. J. New Seed 2008, 9, 68-88. [CrossRef]

44. Abebe, G.; Alemu, A. Role of improved seeds towards improving livelihood and food security at Ethiopia. Int. J. Res. Granthaalayah 2017, 5, 2. [CrossRef]

45. Wild, C.P.; Gong, Y.Y. Mycotoxins and human disease: A largely ignored global health issue. Carcinogenesis 2010, 31, 71-82. [CrossRef] [PubMed]

46. Maddox, D.A. Implications of new technologies for seed health testing and the worldwide movement of seed. Seed Sci. Res. 1998, 8, 277-284. [CrossRef]

47. Berhane, G.; Ragasa, C.; Abate, G.T.; Assefa, T.W. The State of Agricultural Extension Services in Ethiopia and Their Contribution to Agricultural Productivity. ESSP Working Paper 118; International Food Policy Research Institute (IFPRI): Washington, DC, USA, 2018. [CrossRef]

48. Rogers, E.M. Diffusion of Innovations, 5th ed.; Free Press: New York, NY, USA, 2003.

49. Mamuye, W. Determinants of Smallholder Farmers Participation in Formal Credit and Challenges Faced by Institutions: The Case of Mojana Wodera District, Amhara Region, Ethiopia. Int. J. Financ. Bank. Res. 2021, 7, 9-20. [CrossRef] 